\title{
Pelatihan Ekowisata Berbasis Potensi Flora Fauna pada Masyarakat di TWA Gunung Tunak
}

\author{
Gito Hadiprayitno ${ }^{1^{*}}$ dan Dadi Setiadi ${ }^{1}$ \\ ${ }^{I}$ Program Studi Pendidikan Biologi FKIP Universitas Mataram, Mataram, Indonesia
}

DOI: https://doi.org/10.29303/ipmsi.v2i1.23

Citation: Hadiprayitno, G. \& Setiadi, D. 2020. Pelatihan Ekowisata Berbasis Potensi Flora Fauna pada Masyarakat di TWA Gunung Tunak. Jurnal Pengabdian Masyarakat Sains Indonesia (JPMSI). 2(1): 45-51.

Article history

Received: November $15^{\text {th }} 2019$

Revised: December $18^{\text {th }} 2019$

Accepted: December $31^{\text {th }} 2019$

*Corresponding Author: Gito Hadiprayitno, FKIP Universitas Mataram, Mataram, Indonesia; Email:

gitohadiprayitno@unram.ac.id
Abstrak: Telah dilakukan kegiatan pengabdian masyarakat yang bertujuan untuk (1) mengenalkan potensi flora fauna pada masyarakat yang tinggal di sekitar TWA Gunung Tunak, (2) melatih masyarakat untuk melakukan proses identifikasi dan inventarisasi flora fauna dengan mudah, praktis dan bisa digunakan dalam pengembangan ekowisata di TWA Gunung Tunak, dan (3) membuat dan mengembangkan leaflet ekowisata berbasis potensi flora fauna yang ada di TWA Gunung Tunak. Kegiatan pengabdian ini telah dilakukan bersama dengan masyarakat lokal yang tinggal di sekitar TWA Gunung Tunak. Teknik kegiatan pengabdian dilakukan dalam bentuk sosialisasi, pelatihan, dan pendampingan. Kegiatan sosialisasi dilakukan secara klasikal dengan memberikan informasi yang terkait dengan potensi flora fauna yang ada di TWA Gunung Tunak. Sementara itu kegiatan pelatihan dilakukan dengan melakukan survei dan obervasi lapang dalam bentuk identifikasi dan inventarisasi flora fauna yang ada di TWA Gunung Tunak. Hasil pengabdian yang telah dilakukan menghasilkan beberapa point penting di antaranya ialah (1) potensi flora dan fauna yang dapat dikembangkan menjadi ekowisata di TWA Gunung Tunak terdiri dari 32 spesies burung dan 52 spesies kupu, (2) hasil observasi bersama dengan Forum Komunikasi Masyarakat Tunak Besopoq memberikan rekomendasi untuk menggunakan spesies burung target dalam pengembangan ekowisata lebih lanjut di antaranya ialah Caloenas nicobarica, Pitta elegans, Megapodius reinwardt, dan Philemon buceroides, sedangkan spesies kupu-kupu terdiri dari Troides helena dan Pachilopta aristolochiae, dan (3) sosialisasi lebih lanjut potensi flora dan fauna yang ada di TWA Gunung Tunak akan dilakukan oleh Forum Komunikasi Masyarakat Tunak Besopoq dengan membagikan leaflet hasil kegiatan pengabdian ini kepada para wisatawan pada saat berkunjung ke TWA Gunung Tunak dan akan dilakukan secara online melalui webnya Forum Komunikasi Masyarakat Tunak Besopoq.

Kata kunci:Ekowisata, Flora Fauna, Masyarakat Gunung Tuwak

kunjungan wisata NTB yang meningkat dari tahun ke tahun diharapkan dapat meningkatkan kunjungan wisatawan pada kawasan-kawasan konservasi yang secara bersamaan menawarkan potensi kekayaan flora dan faunanya sebagai objek wisata. Salah satu diantaranya ialah kunjungan ke Taman Wisata Alam Gunung Tunak.

Taman Wisata Alam (TWA) Gunung Tunak merupakan salah satu Kawasan konservasi yang berada di Provinsi Nusa Tenggara Barat (NTB).TWA Gunung Tunak ditetapkan sebagai Kawasan konservasi berdasarkan SK Menhut No. 425/Kpts-II/1996 tanggal 9 Agustus 1996.TWA Gunung tunak berlokasi di Desa Mertak,
Pariwisata NTB, 2016) dan diprediksi akan terus meningkat pada tahun-thun berikutnya. Jumlah 
Hadiprayitno et al, Jurnal Pengabdian Masyarakat Sains Indonesia 2020, 2 (1):45-51 DOI : https://doi.org/10.29303/ipmsi.v2i1.23

Kecamatan Pujut, Kabupaten Lombok Tengah dengan luas 312 hektar.Penetapan tersebut didarkan atas beberapa hal, salah satu diantaranya ialah keunikan potensi flora dan fauna yang ditemukan di Gunung Tunak.Berdasarkan data dari Balai Konservasi Sumberdaya Alam (BKSDA) NTB, ditemukan beberapa flora dan fauna khas yang ada di Gunung Tunak.

Beberapa potensi flora dan fauna yang bisa ditemukan di Gunung Tunak terdiri dari pada 5 spesies tumbuhan, 13 spesies burung, 1 spesies rusa, dan 1 spesies babi. Ketigabelas spesies burung tersebut ialah Koakiau (Philemon buceroides), Sesap Madu Topi Sisik (Lichmera lombokia), Raja Udang Biru (Halcyon chloris), Raja Udang Merah (Halcyon sp), Bubut Alang-alang (Centropus bengalensis), Kecial Kuning (Zosterops palpebrosus), Punglor Merah (Zoothera interpress) Burung gosong kaki merah (Megapodius reinwardt), Kuntul karang (Egretta sacra), Kowak malam merah (Nycticorax caledonicus), Trinil (Tringa $s p$ ), Kirik-kirik Australia (Merops ornatus), dan Kepodang (Oriolus chinensis) (BKSDA NTB, 2010).

Hasil penelitian yang dilakukan oleh Hadiprayitno et al. (2017) telah menemukan 32 spesies burung yang termasuk ke dalam 27 famili di TWA Gunung Tunak. Spesies burung dengan kelimpahan tertinggi terdiri dari Orthotomus sepium (13.9\%), Zosterops chloris (12.2\%), dan Streptopelia chinensis (10.4\%).Telah ditemukan juga beberapa spesies burung yang perlu mendapatkan perhatian karena keunikan habitat, status konservasi, dan ciri khusus lainnya diantaranya ialah Dicrurus densus, Pitta elegans, Megapodius reinwardt, dan Cinnyris jugularis.Dicrurus densus, Pitta elegans, dan Megapodius reinwardt merupakan spesies burung yang endemik yang menjadi target pengamatan bagi para pecinta burung karena keunikan habitat, morfologi, dan perilakunya serta hanya ditemukan pada lokasi-lokasi tertentu saja. Disamping itu ditemukan 1 spesies burung yang terancam punah yaitu Caloenas nicobarica yang tidak bisa ditemukan di tempat lain (Myers \& Bishop, 2005; Birlife International, 2012).

Potensi flora dan fauna lain yang dapat ditemukan di TWA Gunung Tunak diantaranya ialah kupu-kupu, capung, herpetofauna, dan beberapa spesies tumbuhan unik yang hanya ditemukan di Kawasan pesisir yang berbatasan langsung dengan Kawasan hutan. Tidak kurang dari
e-ISSN : 2715-2537

p-ISSN : 2715-2545

50 spesies kupu-kupu telah ditemukan di TWA Gunung Tunak, 11 spesies herpetofauna, dan 7 spesies capaung (Hadiprayitno et al., 2017).Sementara itu tipologi spesies tumbuhan yang ditemukan di TWA Gunung Tunak memiliki karakter khusus sebagai ciri khas tumbuhan peralihan dari habitat perairan dan habitat daratan.

Berdasarkan beberapa informasi potensi flora dan fauna hasil penelitian yang sudah diungkapkan tersebut menunjukkan bahwa keberadaan TWA Gunung Tunak diharapkan dapat memberikan kontribusi positif dalam pengembangan Kawasan konservasi, pelestarian plasma nutfah, penyelamatan ekologi serta memberikan kontribusi dalam meningkatkan perekonomian masyarakat yang ada di sekitarnya. Implementasi dari harapan tersebut telah dilakukan oleh BKSDA NTB dengan melakukan kegiatan penangkaran rusa dan kupu-kupu khas NTB bekerjasama dengan pihak Korea Selatan.Kegiatan ini diharapkan dapat menyelematkan potensi flora fauna yang ada di NTB serta mendorong pengembangan kegiatan ekowisata berbasis potensi flora fauna yang ada di NTB.

Namun demikian pengembangan kegiatan ekowisata yang maju dan menarik untuk dikunjungi tidak hanya menyiapkan sarana wisata dalam bentuk penangkaran semata. Penyiapan sumberdaya manusia yang akan melakukan kegiatan pendampingan dalam pengembangan kegiatan ekowisata perlu juga dipersiapkan (Aswin \& Ardash, 2007). Karena itu, masyarakat sekitar yang tinggal berdekatan dengan TWA Gunung Tunak Perlu diberikan pengetahuan dan wawasan yang memadai terkait dengan potensi flora dan fauna yang ada di TWA Gunung Tunak sehingga dapat dilibatkan dalam kegiatan-kegiatan pengembangan ekowisata yang ada di TWA Gunung Tunak. Pelibatan masyarakat dalam bentuk seperti ini bernilai positif untuk menyelamatkan dan melestarikan potensi flora dan fauna yang ada serta dapat dijadikan sebagai sarana wisata yang menyenangkan dan dapat memberikan kontribusi positif dalam meningkatkan perekonomian atau kesejahteraan masyarakat.Berdasarkan hal tersebut dipandang perlu untuk melakukan kegiatan pengabdian dalam bentuk memberikan pelatihan ekowisata berbasis potensi flora dan fauna pada masyarakat yang ada di sekitar TWA Gunung Tunak. 
Hadiprayitno et al, Jurnal Pengabdian Masyarakat Sains Indonesia 2020, 2 (1):45-51 DOI : https://doi.org/10.29303/ipmsi.v2i1.23

\section{Metode}

Metode pelaksanaan kegiatan pengabdian masyarakat ini difokuskan pada upaya penyelesaian masalah yang sedang dihadapi oleh masyarakat yaitu kurangnya pengetahuan masyarakat terkait potensi ekowisata berbasis flora dan fauna di TWA Gunung Tunak serta kurangnya kemampuan teknis dalam masyarakat melaksanakan observasi flora dan fauna di TWA Gunung Tunak. Permasalahan tersebut diharapkan dapat diatasi melalui pendekatan pelatihan kepada masyarakat terkait potensi ekowisata flora dan fauna di TWA Gunung Tunak.

Kegiatan pelatihan dan sosialisasi dilakukan untuk memberikan penjelasan yang komprehensif tentang potensi ekowisata berbasis flora dan fauna bagi pengembangan konservasi dan wisata di TWA Gunung Tunak serta peluang mata pencarian yang dapat dimanfaatkan oleh masyarakat pada skema ekowisata berbasis flora dan fauna di TWA Gunung Tunak oleh tim pengabdian. Secara teknis, pelatihan ekowisata brebasis flora dan fauna di TWA Gunung Tunak terdiri atas tiga kegiatan yaitu 1) penyampaian materi, diskusi dan tanya jawab terkait potensi ekowisata flora dan fauna di TWA Gunung Tunak dan 2) pelatihan teknik observasi flora dan fauna, 3) Diskusi dan tanya jawab pembuatan dan penggunaan leaflet berbasis flora dan fauna di TWA Gunung Tunak. Peserta pelatihan forum komunikasi masyarakat Tunak Besopoq dengan jumlah peserta sebanyak 20 orang.

Penyampaian materi merupakan bentuk sosialiasi kepada masyarakat mengenai peran penting flora dan fauna di TWA Gunung Tunak sebagai objek wisata. Dengan demikian, masyarakat dapat melihat peluang ekonomi yang dapat sangat berpotensi menjadi sumber pendapatan baru dari adanya ekowisata berbasis flora dan fauna di TWA Gunung Tunak.

Pelatihan teknik observasi flora dan fauna merupakan kegiatan praktek yang bertujuan mendemonstrasikan berbagai macam teknik pengamatan atau observasi flora dan fauna sehingga masyarakat dapat menguasai berbagai macam teknik pengamatan tersebut. Beberapa teknik yang akan dilatih yaitu teknik pengamatan dan identifikasi burung, kupu-kupu dan tumbuhan yang memiliki daya tarik konservasi, keindahan dan kelangkaan. Teknik pengamatan tersebut sangat dibutuhkan bagi masyarakat yang ingin
e-ISSN : 2715-2537

p-ISSN : 2715-2545

memanfaatkan potensi ekowisata berbasis flora dan fauna di TWA Gunung Tunak. Selain teknik-teknik pengamatan flora dan fauna, tim pengabdian juga akan mendemonstrasikan beragai teknik-teknik fotografi flora dan fauna untuk melengkapi kompetensi masyarakat dalam menekuni profesi pemandu ekowisata. Teknik fotografi sangat penting bagi setiap pemandu ekowisata berbasis flora dan fauna di TWA Gunung Tunak karena aktivitas ekowisata yang sangat berhubungan dengan dunia fotografi, selain itu kompetensi fotografi yang baik juga dapat menjadi salah satu kompetensi yang memiliki daya jual yang tinggi dalam menawarkan ekowisata yang profesional.

Kegiatan diskusi pembimbingan pembuatan dan penggunaan pleaflet ekowisata berbasis flora dan fauna di TWA Gunung Tunak dilakukan untuk menghasilkan panduan ekowisata yang menarik dan mudah untuk digunakan baik oleh masyarakat yang ingin menjadi pemandu ekowisata. Leaflet ekowisata di TWA Gunung Tunak akan memudahkan masyarakat dalam memandu pengunjung untuk menemukan spot terbaik ekowisata yang ada di TWA Gunung Tunak.

Kegiatan pelatihan ekowisata berbasis potensi flora fauna pada masyarakat di TWA Gunung Tunak dilaksanakan pada tanggal 2 September 2018 s.d 30 Oktober 2018. Kegiatan terdiri atas sosialisasi/pelatihan dan praktek pembuatan dan penggunaan leaflet ekowisata berbasis potensi flora fauna yang ada di TWA Gunung Tunak. Sosialisasi dan pelatihan dilaksanakan pada tanggal 10 Oktober 2018. Sosialisasi dilakukan oleh tim pengabdian kepada Forum Komunikasi Masyarakat Tunak Besopoq di TWA Gunung Tunak dengan jumlah peserta sebanyak 20 orang. Kegiatan Sosialisasi dilakukan untuk menyampaikan materi terkait potensi flora dan fauna sebagai destinasi ekowisata di TWA Gunung Tunak. Sementara kegiatan praktek dilakukan melalui pembinaan dan pemanduan dalam pembuatan dan penggunaan leaflet ekowisata berbasis potensi flora fauna yang ada di TWA Gunung Tunak.

\section{Hasil dan Pembahasan Survei potensi flora dan fauna di TWA Gunung Tunak}

Kegiatan survei dilakukan untuk mengetahui keanekaragaman potensi flora dan fauna serta flora dan fauna unggulan yang dapat 
Hadiprayitno et al, Jurnal Pengabdian Masyarakat Sains Indonesia 2020, 2 (1):45-51 DOI : https://doi.org/10.29303/ipmsi.v2i1.23

diperkenalkan di TWA Gunung Tunak.Hasil survei menemukan beberapa jenis fauna yang memiliki nilai ekowisata yaitu burung dan kupukupu.Berdasarkan survei menunjukkan bahwa spesies burung yang ditemukan di TWA Gunung Tunak terdiri dari 32 spesies burung dan 52 spesies Kupu-kupu (Tabel 1).Akan tetapi spesies kupukupu yang berhasil diidentifikasi dengan baik berjumlah 39 spesies.

Tabel 1 Spesies Burung dan Kupu-kupu di TWA Gunung Tunak

\begin{tabular}{|c|c|c|c|}
\hline No & Jenis Burung & No & Jenis Burung \\
\hline 1 & Elang Bondol & 17 & $\begin{array}{l}\text { Kipasan dada } \\
\text { hitam }\end{array}$ \\
\hline 2 & $\begin{array}{l}\text { Elang Laut perut } \\
\text { putih }\end{array}$ & 18 & Kacamata laut \\
\hline 3 & Pitta & 19 & Kuntul kecil \\
\hline 4 & gosong kaki merah & 20 & Cabai lombok \\
\hline 5 & Srigunting walacea & 21 & $\begin{array}{l}\text { Kipasan sayap } \\
\text { putih }\end{array}$ \\
\hline 6 & Koak Kaok & 22 & Kehicap ranting \\
\hline 7 & Kirik-kirik laut & 23 & Cinenen jawa \\
\hline 8 & Tekukur & 24 & Gelatik batu \\
\hline 9 & Isap Madu & 25 & Pergam hijau \\
\hline 10 & $\begin{array}{l}\text { Kepudang kuduk } \\
\text { hitam }\end{array}$ & 26 & Kuntul karang \\
\hline 11 & Cekakak sungai & 27 & Bubut alang-alang \\
\hline 12 & Ayam Hutan Merah & 28 & Bentet kelabu \\
\hline 13 & Ayam Hutan Hijau & 29 & $\begin{array}{l}\text { Sikatan dada } \\
\text { merah }\end{array}$ \\
\hline 14 & Buntut sate putih & 30 & Junai emas \\
\hline 15 & Puyuh loreng & 31 & Dara laut \\
\hline 16 & Cerukcuk & 32 & Alap-alap \\
\hline No & Spesies Kupu-Kupu & No & $\begin{array}{l}\text { Spesies Kupu- } \\
\text { Kupu }\end{array}$ \\
\hline 1 & Apphias albina & 18 & $\begin{array}{l}\text { Hypolimnas } \\
\text { bolina }\end{array}$ \\
\hline 2 & Apphias lyncida & 19 & Idiopsis juventa \\
\hline 3 & Applas oferna & 20 & Januides sp \\
\hline 4 & Athyma nefta & 21 & Junonia erigone \\
\hline 5 & Catopshila pyranthe & 22 & $\begin{array}{l}\text { Spesies Kupu- } \\
\text { Kupu }\end{array}$ \\
\hline 6 & Catopsila pomana & 23 & Meduza procris \\
\hline 7 & Cepora & 24 & Neptis hylas \\
\hline 8 & Cepora evelith & 25 & $\begin{array}{l}\text { Pachiopta } \\
\text { aristolochiae }\end{array}$ \\
\hline 9 & Cupha erymanthis & 26 & Papilia menom \\
\hline 10 & Danaus chrysippus & 27 & Papilia palytes \\
\hline 12 & Euploea eunice & 28 & Papilio peranthus \\
\hline
\end{tabular}

e-ISSN : 2715-2537

p-ISSN : 2715-2545

13 Euploea tulliolus

14 Eurema hecabe

15 Graphium agamenom

16 Hebomoia $s p$

17 Hemomia glaucippe

Lebih lanjut dari keseluruhan spesies tersebut terdapat beberapa spesies unggulan ekowisata berdasarkan pertimbangan eksotisme, nilai konservasinya dan frekuensi perjumpaan yaitu 4 jenis burung di antaranya ialah Junai emas (Caloenas nicobarica), Paok la'us (Pitta elegans), Burung gosong kaki merah (Megapodius reinwardt), dan Koak Kaok (Philemon buceroides) dan2 Jenis Kupu-kupu yaitu Kupu-kupu Raja (Troides helena) dan Pachilopta aristolochiae.

Berdasarkan hasil survei pada Tabel 1 terdapat 14 spesies burung (44\%) yang ditemukan di TWA Gunung Tunak merupakan spesies burung yang berperan penting dalam konservasi. Dua belas spesies burung (86\%) dari spesies burung yang berperan penting dalam konservasi merupakan spesies burung yang dilindungi oleh undangundang berdasarkan PP No. 7 tahun 1999. Sementara itu, $14 \%$ sisanya (2 spesies burung) merupakan burung endemik di Kawasan Wallacea.Ditemukannya spesies burung yang dilindungi oleh undang-undang dan spesies burung yang bersifat endemik untuk kawasan Wallacea, memungkinkan untuk menjadikan TWA Gunung Tunak sebagai kawasan yang berperan penting dalam melakukan kegiatan konservasi burung.Hasil survei ini memberikan informasi penting yang dapat digunakan sebagai informasi untuk menetapkan kegiatan tersebut.

\section{Sosialisasi potensi flora fauna TWA Gunung Tunak}

Kegiatan sosialisasi diikuti oleh peserta yang berasal dari kelompok masyarakat wisata Desa Mertak yaitu Forum Komunikasi Tunak Besopoq dengan jumlah peserta sebanyak 20 orang.Kegiatan sosialisasi dilakukan untuk memberikan penjelasan yang komprehensif tentang potensi ekowisata berbasis flora dan fauna bagi pengembangan konservasi dan wisata di TWA Gunung Tunak serta peluang mata pencaharian yang dapat dimanfaatkan oleh masyarakat pada skema ekowisata berbasis flora dan fauna.Selain itu kegiatan sosialisasi dilakukan untuk mensosialisasikan hasil survei spesies burung dan 
Hadiprayitno et al, Jurnal Pengabdian Masyarakat Sains Indonesia 2020, 2 (1):45-51 DOI : https://doi.org/10.29303/ipmsi.v2i1.23

kupu-kupu yang ditemukan di TWA Gunung Tunak.Gambaran umum terkait kondisi pada saat sosialisasi dapat dilihat pada Gambar 1.

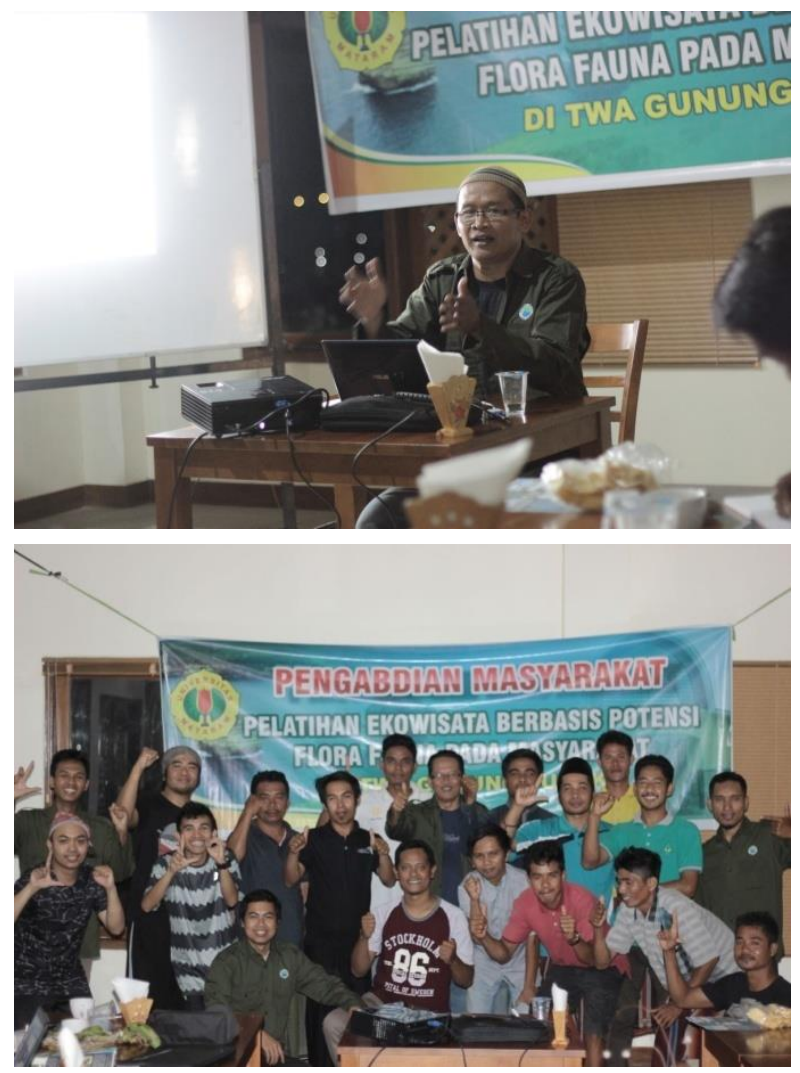

Gambar 1 Sosialisasi Potensi Flora dan Fauna di TWA Gunung Tunak

Kegiatan sosialisasi yang dilakukan dalam kegiatan ini mendapatkan apresiasi dari masyarakat yang tiggal di sekitar TWA Gunung Tunak.Kegiatan sosialisasi yang didasarkan atas hasil survei flora fauna yang ada di TWA Gunung Tunak pertama kali dilaksanakan.Kegiatan semacam ini dapat dijadikan sebagai bentuk penguatan masyarakat dalam melestarikan potensi flora fauna yang ada di lingkungan sekitar tempat tinggalnya.

Hasil sosialisasi juga mengungkap beberapa potensi lokal masyarakat yang dapat dikembangkan untuk dikemas menjadi kegiatan ekowisata.Masyarakat sudah sejak lama memiliki kearifan lokal dalam melestarikan potensi sumberdaya yang diturunkan secara turun temurun sampai dengan saat ini.Salah satu bentuk kearifan lokal yang masih bertahan sampai sekarang ialah ritual "Petaik Kao". Ritual ini dilakukan oleh masyarakat dengan cara melapaskan kerbau ke hutan untuk mencari makan sendiri tanpa harus
e-ISSN : $2715-2537$

p-ISSN : 2715-2545

digembala. Ritual seperti ini ditujukan untuk memastikan bahwa kondisi hutan yang ada di lingkungan sekitar masih dalam kondisi baik sehingga mampu mendukung kehidupan kerbau yang dipelihara masyarakat sekitar.Melalui kegiatan ritual seperti ini, masyarakat menjadi pantangan untuk merusak hutan karena dikhawatirkan bisa menyebabkan berkurangnya sumberdaya hutan yang dapat mengakibatkan berkurangnya sumber pakan kerbau yang menjadi bagian penting bagi kehidupan masyarakat yang tinggal di sekitar TWA Gunung Tunak.

Hasil kegiatan sosialisasi yang lain juga mengungkapkan bahwa Kawasan TWA Gunung Tunak meruapakan hutan adat yang dipertahankan oleh masyarakat karena memiliki sejarah masa lalu yang memiliki nilai sosio kultural tertentu bagi masyarakat dalam berinteraksi dengan alam. Terdapat beberapa lokasi dan aktivitas masyarakat yang dapat memberikan kontribusi terhadap pelestarian flora fauna yang ada di TWA Gunung Tunak.Gunung Raden dan Bagik Pondok (Gunung Buwuh) merupakan salah satu lokasi yang dianggap penting oleh masyarakat. Gunung Raden dapat memberikan cerminan masyarakat untuk tidak membeda-bedakan antara masyarakat biasa dengan masyarakat bangsawan, semuanya dianggap sama tidak ada bedanya satu sama lain. Masyarakat tidak bisa sembarangan memasuki Gunung Raden ini tanpa ijin dari Pemangku Adat. Tempat ini tidak pernah diganggu sama sekali oleh masyarakat sehingga mengakibatkan kondisi sumberdaya yang ada di dalamnya masih utuh. Masyarakat yang memanfaatkan flora fauna yang ada di Gunung Raden akan mengalami kejadian-kejadian yang tidak wajar.

Kejadian-kejadian yang sering dialami di antaranya ialah kesurupan.Kesurupan ini terjadi apabila masyarakat mengambil burung gosong (Megapodius reinwardt) untuk dijadikan sebagai hewan peliharaan. Konsekuensi dari fenomena ini ialah burung gosong yang ada di TWA Gunung Tunak kondisinya sangat stabil dibandingkan yang ada di tempat lain. Hasil survei juga membuktikan adanya sarang burung gosong yang masih aktif yang jumlahnya lebih dari 10 sarang.Bahkan pada saat berjalan-jalan di TWA Gunung tunak terkadang ditemukan beberapa individu burung yang tidak terganggu dengan aktivitas masyarakat yang ada di sekelilingnya.

Selama kegiatan sosialisasi juga terungkap bahwa pola pengelolaan TWA Gunung Tunak 
Hadiprayitno et al, Jurnal Pengabdian Masyarakat Sains Indonesia 2020, 2 (1):45-51 DOI : https://doi.org/10.29303/ipmsi.v2i1.23

dilakukan melalui kegiatan kemitraan bersama dengan masyarakat.Pola kemitraan ini dilakukan setelah ada kegiatan kerjasama antara pemerintah Indonesia dengan Korea Selatan.Pengembangan sarana dan prasarana yang ada di TWA Gunung Tunak seperti penangkaran rusa, penangkaran kupu-kupu, pembangunan fasilitas penginapan, aula pertemuan, dan rumah makan telah dibuat sebagai hasil dari kerjasama tersebut. Kelompok masyarakat yang tergabung dalam Forum Komunikasi Masyarakat Tunak Besopoq diberikan kewenangan dalam melakukan kegiatan penyedia jasa seperti petugas kebersihan, penjaga penginapan, penyedia jasa boga, fasilitator yang mendampingi para wisatawan (guide), dan penyedia jasa yang lainnya. Melalui pola kemitraan seperti ini, masyarakat merasa dihargai dan diberikan peran yang besar dalam menjaga dan melestarikan potensi sumberdaya yang ada di TWA Gunung Tunak.

Pola kemitraan semacam ini dalam jangka panjang diharapkan dapat menjadi model yang bisa diimplementasikan di tempat lain. Namun demikian, apabila keterlibatan masyarakat ini tidak bisa memberikan nilai positif dalam mengatasi pengangguran dan peningkatan pendapatan, dikhawatirkan model kemitraan seperti ini tidak bisa berlangsung lama.Pihak pengelola TWA Gunung Tunak dan masyarakat harus bekerja keras untuk mengupayakan kunjungan wisatawan mengalami kenaikan dari tahun ke tahun.Meningkatnya jumlah wisatawan diharapkan dapat memberikan pengaruh terhadap penyedia jasa dan layanan yang lainnya.Karena itu, keterlibatan Forum Komunikasi Masyarakat Tunak Besopoq dalam melakukan kegiatan pengelolaan di TWA Gunung Tunak diharapkan dapat berjalan beriringan dengan misi BKSDA dalam melestarikan flora fauna.Model pelestarian melalui kegiatan kemitraan seperti ini diharapkan dapat memberikan dampak positif terhadap peningkatan kesejahteraan masyarakat yang tinggal di sekitar Kawasan TWA Gunung Tunak.

\section{Pelatihan identifikasi dan inventarisasi flora fauna TWA Gunung Tunak}

Pelatihan identifikasi dan inventarisasi dilakukan melalui kegiatan praktik pengamatan flora dan fauna di TWA Gunung Tunak.Pelatihan identifikasi dilakukan untuk melatih kemampuan kelompok masyarakat wisata "Tunak Besopoq" untuk melakukan pengamatan dan identifikasi
e-ISSN : 2715-2537

p-ISSN : 2715-2545

khususnya fauna burung dan kupu-kupu secara tepat sesuai dengan kaidah wisata dan keberlanjutan ekologi fauna di TWA Gunung Tunak.Akan tetapi, sebelum melakukan pengamatan, masyarakat terlebih dahulu dilatih untuk mempersiapkan perlengkapan yang dibutuhkan.Alat utama adalah teropong (binokuler) dengan berbagai ukuran lensa yang disesuaikan dengan kebutuhan.Binokuler yang ideal untuk pengamatan di hutan adalah yang berukuran lensa 10x50mm, menghasilkan gambar yang jelas dan ringan untuk dibawa pada saat pengamatan.Binokuler yang lebih lebih ringan berukuran lensa 10x30mm dianjurkan untuk mengamati burung-burung kecil yang lebih lincah.Pada pengamatan di areal tebuka disa rankan menggunakan binokuler berukuran lensa besar 10x70mm karena jarak pandangnya lebih jauh dan luas.Sementera, untuk pengamatan burung-burung air di lahan basah tidak hanya menggunakan binokuler, tapi juga dapat menggunakan monokuler yang mempunyai ukuran lensa lebih besar yaitu $15 \times 70 \mathrm{~mm}$ dengan perbesaran beberapa puluh kali.

Kemampuan masyarakat dalam melakukan kegiatan identifikasi dan inventarisasi flora fauna yang ada di TWA Gunung Tunak pada dasarnya bukan menjadi kendala utama dalam memberikan layanan terhadap para wisatawan.Masyarakat sudah mengenal dengan baik flora fauna yang ditemukan di TWA Gunung Tunak meskipun hanya dengan menggunakan peralatan seadanya dan istilah-istilah yang digunakan masih menggunakan Bahasa lokal. Kendala utama yang perlu dicarikan solusinya adalah penyediaan peralatan penunjang berupa teropong binokuler, buku panduan, dan biaya operasional kegiatan penangkaran kupu-kupu serta penyediaan fasilitas wisatawan seperti sepeda, layanan out bound, dan kamera.

Kendala utama yang perlu dicarikan solusinya segera ialah keterlibatan masyarakat dalam melakukan kegiatan penangkaran kupukupu.Fasilitas penangkaran kupu-kupu yang ada di TWA Gunung Tunak merupakan yang terlengkap dan terbesar di NTB.Akan tetapi biaya operasional dalam mengembangkan kegiatan penangkaran kupu-kupu masih sangat terbatas.Karena itu masyarakat perlu dibantu dalam mengatasi persoalan ini.Pengelola TWA Gnung Tunak dan forum komunikasi masyarakat Tunak Besopoq sepertinya perlu melakukan kegiatan studi banding ke pusat penangkaran kupu-kupu yang ada di Bali dan Bantimurung (Sulawesi Selatan). Kedua tempat 
Hadiprayitno et al, Jurnal Pengabdian Masyarakat Sains Indonesia 2020, 2 (1):45-51 DOI : https://doi.org/10.29303/ipmsi.v2i1.23

ini telah berhasil mengembangkan kegiatan penangkaran kupu-kupu yang telah dijadikan sebagai objek utama tujuan para wisatawan.

\section{Kesimpulan}

Kesimpulan yang dihasilkan dari pelaksanaan kegiatan pengabdian kepada masyarakat yang dilaksanakan di TWA Gunung Tunak ini di antaranya ialah (1) Potensi flora dan fauna yang dapat dikembangkan menjadi ekowisata di TWA Gunung Tunak terdiri dari 32 spesies burung dan 52 spesies kupu, (2) Hasil observasi Bersama dengan Forum Komunikasi Masyarakat Tunak Besopoq memberikan rekomendasi untuk menggunakan spesies burung target dalam pengembangan ekowisata lebih lanjut di antaranya ialah Caloenas nicobarica, Pitta elegans, Megapodius reinwardt, dan Philemon buceroides, sedangkan spesies kupu-kupu terdiri dari Troides helena dan Pachilopta aristolochiae, dan (3) Sosialisasi lebih lanjut potensi flora dan fauna yang ada di TWA Gunung Tunak akan dilakukan oleh Forum Komunikasi Masyarakat Tunak Besopoq dengan membagikan leaflet hasil kegiatan pengabdian ini kepada para wisatawan pada saat berkunjung ke TWA Gunung Tunak dan akan dilakukan secara online melalui webnya Forum Komunikasi Masyarakat Tunak Besopoq.

\section{Saran}

Kegiatan ini sebaiknya lebih sering dilakukan dan melibatkan lebih banyak komunitaskomunitas yang ada di Gunung Tuwak untuk memberikan pengetahuan kepada masyarakat terkaitpotensi ekowisata berbasis flora dan fauna sehingga peluang mata pencaharian dari konservasi wisata tersebut dapat dimanfaatkan oleh masyarakat.

\section{Ucapan Terima Kasih}

Terima kasih kami ucapkan kepada Terima kasih kami ucapkan kepada Universitas Mataram yang telah memberikan dana untuk kegiatan ini melalui sumber dana DIPA BLU (PNBP) Universitas Mataram.

\section{Daftar Pustaka}

Aswin, S., \& Ardash, B. (2007). Ecotourism: A Perspective from Thai Youths. Journal of

\author{
e-ISSN : 2715-2537 \\ p-ISSN : 2715-2545 \\ Hospitality, Leisure, Sport \& Tourism \\ Education, 6 (1), 81-85.
}

BirdLife International.(2012). Caloenas

nicobarica.The IUCN Red List of Threatened

Species.(Online). Diakses di

http://dx.doi.org/10.2305/IUCN.UK.20121.R

LTS.T22690974A38288253.en

BKSDA NTB. 2010. Panduan Wisata Alam di Kawasan Konservasi Nusa Tenggara Barat.

Dinas Pariwisata NTB. 2016. Rekapitulasi Kunjungan Wisatawan ke NTB Tahun 20132015.(Online).Diakses dari http://www.disbudpar.ntbprov.go.id.

Hadiprayitno, G., Al Idrus, A., Mertha, I. G., \& Ilhamdi, M. L. (2017). Komunitas Burung dan Pengembangannya sebagai Buku Panduan Pengamatan Burung di Taman Wisata Alam Gunung Tunak Lombok Tengah. (Laporan Penelitian). Mataram: Universitas Mataram.

Myers, S. D., \& Bishop, K. D. (2005).A review of historic and recent bird records from Lombok, Indonesia. Forktail, 21, 147-160. 